\title{
Bringing fresh produce to corner stores in declining neighborhoods: Reflections from Detroit FRESH
}

\author{
Kameshwari Pothukuchi* \\ Wayne State University
}

Submitted February 17, 2016 / Revised July 5 and October 12, 2016 / Accepted October 14, 2016 /

Published online December 20, 2016

Citation:. Pothukuchi, K. (2016). Bringing fresh produce to corner stores in declining neighborhoods:

Reflections from Detroit FRESH. Journal of Agriculture, Food Systems, and Community Development, 7(1),

113-134. http://dx.doi.org/10.5304/jafscd.2016.071.013

Copyright (C) 2016 by New Leaf Associates, Inc.

\begin{abstract}
The paper reports and reflects on an action research project to increase availability and sales of fresh produce in 26 neighborhood corner stores in Detroit, Michigan. Through analysis of neighborhood, store-related, and supply-chain characteristics, I identify factors in successful operations as well as challenges confronted by stores between 2009 and 2012, when many Detroit neighborhoods lost population due to tax foreclosure and abandonment. Neighborhood distress was reflected in challenges experienced by a majority of stores, including those that dropped out of the project prematurely (five out of seven), or participated only inconsistently (seven out of 10). Nine stores
\end{abstract}

* Kameshwari Pothukuchi, Ph.D., Associate Professor and Chair, Department of Urban Studies and Planning, Wayne State University; 3198 Faculty Administration Building; Detroit, Michigan 48202 USA; +1-313-577-4296;

k.pothukuchi@wayne.edu supplied fresh produce consistently. Operators with high levels of performance tended to be in zip codes experiencing population losses at a lower rate than the citywide average, be more committed to their store-neighborhood, have more experience with fresh produce sales, and be more willing to test alternatives. This paper reflects on the challenges of implementing corner store strategies in rapidly depopulating neighborhoods without ongoing subsidy. It also demonstrates the lessons in implementing them as action research projects including with students and community partners.

\section{Keywords}

Healthy Corner Stores; Food Access; Neighborhood Decline; Detroit

\section{Acronyms}

CSK Capuchin Soup Kitchen

DUFB Double Up Food Bucks 


$\begin{array}{ll}\text { EWUF } & \text { Earthworks Urban Farm } \\ \text { F\&V } & \text { Fruits and vegetables } \\ \text { NAICS } & \begin{array}{l}\text { North American Industrial Classification } \\ \text { System }\end{array} \\ \text { SIC } & \begin{array}{l}\text { Standard Industrial Classification } \\ \text { SNAP }\end{array} \\ & \begin{array}{l}\text { Supplemental Nutrition Assistance } \\ \text { Program, also known as food stamps }\end{array} \\ \text { USDA } & \text { U.S. Department of Agriculture } \\ \text { WIC } & \begin{array}{l}\text { Special Supplemental Nutrition Assistance } \\ \text { Program for Women, Infants, and Children }\end{array} \\ \text { WSU } & \text { Wayne State University }\end{array}$

\section{Introduction}

Detroit, Michigan, is the locus of many collaborative food-system activities to increase access to fresh and healthy food through urban agriculture, neighborhood farmers markets, farm-to-school and/or -cafeteria initiatives, and community nutrition education. Efforts also exist to develop supportive policy frameworks and financing initiatives (Pothukuchi, 2011, 2015). Led mostly by community-based organizations, these efforts collectively seek to satisfy the food and economic needs of residents, while repairing gaps in the conventional food supply and building a more just alternative to it. Over the last decade, corner stores have emerged as possible resources for healthy foods in impoverished urban neighborhoods.

This paper elaborates on the experiences of and lessons from one such pilot initiative, Detroit FRESH, developed within a broader set of community food-system collaborations led by its parent organization, SEED Wayne. ${ }^{1}$ Between 2008 and 2011, Detroit FRESH assessed and attempted to recruit 214 stores in some of Detroit's poorest neighborhoods on the east side and near west side. I describe and reflect on the initiative's successes and limitations in a context of extreme and ongoing neighborhood decline. The analysis highlights the relationship of the typical corner store to its supply chain and to neighborhood residents' food

\footnotetext{
${ }^{1}$ SEED Wayne is a campus-community collaborative dedicated to building student leadership in sustainable food systems through activities in teaching, research, and engagement. On campus, student-led activities include three vegetable gardens, a 22-week farmers market, and hands-on workshops related to healthy eating. In the community, SEED
}

acquisition patterns. It traces the possibilities for, and limits to, increasing the supply of fresh produce in neighborhoods through partnerships with corner stores, and discusses the implications of doing so in a collaborative action research project involving students and community partners.

As this paper shows, corner store initiatives in neighborhoods experiencing significant decline cannot be sustained without ongoing subsidy. Initiatives also require businesspeople with specific commitments atypical to their category. The paper documents - albeit through a small sample of participating stores - the store, distribution, and community conditions needed for successful, sustainable corner store initiatives in such low income urban neighborhoods. A brief review of the literature is followed by a discussion of rationales for corner store strategies, and project methods and outcomes. A concluding section interprets findings and offers recommendations recognizing that conditions of such widespread and deep decline are relatively rare.

\section{Corner Store Initiatives: Research and Rationales}

Healthy food access in urban communities is a much researched topic. Low income, predominantly African American urban neighborhoods tend to have a paucity of grocery supermarkets relative both to the demand that exists there as well as to their white counterparts (Alwitt \& Donley, 1997; Galvez et al., 2008; Hendrickson, Smith, \& Eikenberry, 2006; Morland \& Filomena, 2007; Pothukuchi, 2005; Social Compact, 2010; Zenk, Schulz, Israel et al., 2005). Such neighborhoods also have an overabundance of convenience and liquor stores and fast food outlets (Block et al., 2004; Moore \& Diez Roux, 2006; Morland, Wing, Diez Roux, \& Poole, 2002; Powell, Chaloupka, \& Bao, 2007; Vallianatos, Azuma, Gilliland, \& Gottlieb, 2010). Corner stores located here also

Wayne supports entrepreneurial agriculture in a 4,000 sq. $\mathrm{ft}$. (372 sq. m) passive solar greenhouse it helped build, neighborhood-based access to fresh produce, and healthy eating workshops. For more details, read Pothukuchi (2012) or browse http://clas.wayne.edu/seedwayne. 
offer few choices in healthy and fresh foods (Algert, Agrawal, \& Lewis, 2006; Cavanaugh, Mallya, Brensinger, Tierney, \& Glanz, 2013; Gittelsohn et al., 2008; Horowitz, Colson, Hebert, \& Lancaster, 2004; Lucan, Karpyn, \& Sherman, 2010; Sharkey, Dean, \& Nalty, 2012). Consequently, residents in these neighborhoods experience higher food prices, fewer nutritious choices, and lower quality of products that are available there (Andreyeva, Blumenthal, Schwarts, Long, \& Brownell, 2008; Franco, Diez Roux, Glass, Caballero, \& Brancati, 2008; Zenk, Schulz, Hollis-Neely et al., 2005).

However, not all poor urban neighborhoods lack healthy food retail options (Block \& Kouba, 2006; Eckert \& Shetty, 2011; Raja, Ma, \& Yadav, 2008; Short, Guthman, \& Raskin, 2007). If, and to what extent, change in the neighborhood food environment can reverse obesity is also subject to debate (Bader et al., 2013; Ford \& Dzewaltowski, 2010; Guthman, 2013; Osypuk \& Acevedo-Garcia, 2010).

In this paper, I take as a starting point the normative urban planning argument that neighborhoods ought to provide the basics of daily life (Wekerle, 1985). As discussed previously, this is far from the reality in many urban neighborhoods whose residents shop at more distant supermarkets, a pattern confirmed for Detroit by Ledoux and Vojnovic (2013). Because members of dominant groups have both greater mobility and more resources, the idea of neighborhoods as service centers in low-income communities of color is therefore a matter of social and environmental justice (Agyeman \& Evans, 2004; Wilson, Hutson, $\&$ Mujahid, 2008). Corner stores are a fixture in low-income, urban neighborhoods; they therefore offer a potential starting point for initiatives to increase year-round supply of fresh and healthy foods.

Corner stores are shown to be a viable strategy for increasing supply and sales of healthy food products in several cities, including Baltimore, Maryland; New York; New Orleans, Louisiana; and San Francisco (Dannefer, Williams, Baronberg, \& Silver, 2012; Gittelsohn et al., 2010, 2012; Martin et al., 2012; Song et al., 2009). They show promising results from the perspective of availability and sales of healthy products, especially when combined with nutrition education (Gittelsohn et al., 2012).
Although identified as an important factor (for example, by O’Malley, Gustat, Rice, \& Johnson, 2013), less is known about distribution networks to help stores become self-sustaining. We also know little about the effects of neighborhood abandonment on corner stores' inclination or ability to offer healthy foods or the factors that separate effective performers from others. This study seeks to close this gap; it also illuminates the coordination needed to link corner stores to distributors as well as to facilitate neighborhood demand so as to create a self-sustaining cycle of supply.

Corner store strategies make sense for several reasons in Detroit. First, the stores represent a preexisting retail infrastructure within impoverished neighborhoods that larger retailers shun. They have existing relationships with food and beverage distributors. Many also have the capacity to accept government nutrition programs such as SNAP (Supplemental Nutrition Assistance Program) and WIC (Special Supplemental Nutrition Assistance for Women, Infants, and Children). Second, store owners may get to know their customers and may develop long-term relationships with local residents and organizations, especially when cultural congruence exists between the operator and shoppers such as might be the case in Mexican Town or Bangla Town neighborhoods (see, for example, Kaufman \& Hernandez, 1991). Finally, they may hire residents, offer credit, or carry specific products requested by shoppers (Kaufman \& Hernandez, 1991; McLean \& Bates, 2003). Relations between corner stores and the community in many cities are also characterized by tensions due to differences in ethnic and racial—not to mention, class-backgrounds of store owners and operators and neighborhood residents (Berry, 1998; Cho, 1993; Fisher, 2012; Gold, 2010; Meredith, 1999).

\section{Detroit's Retail Grocery Context}

Detroit's retail grocery needs to be understood in the context of steady decline over the past 60 years. Detroit's population peaked in 1950 at 1.86 million but shrank to 951,307 in 2000 and to a mere 713,777 by 2010 (U.S. Census Bureau, n.d.-a; 1998) (see Map 1). More than four out of five city residents are African American, compared with 
Map 1. City of Detroit, Population Change, 2000-2010

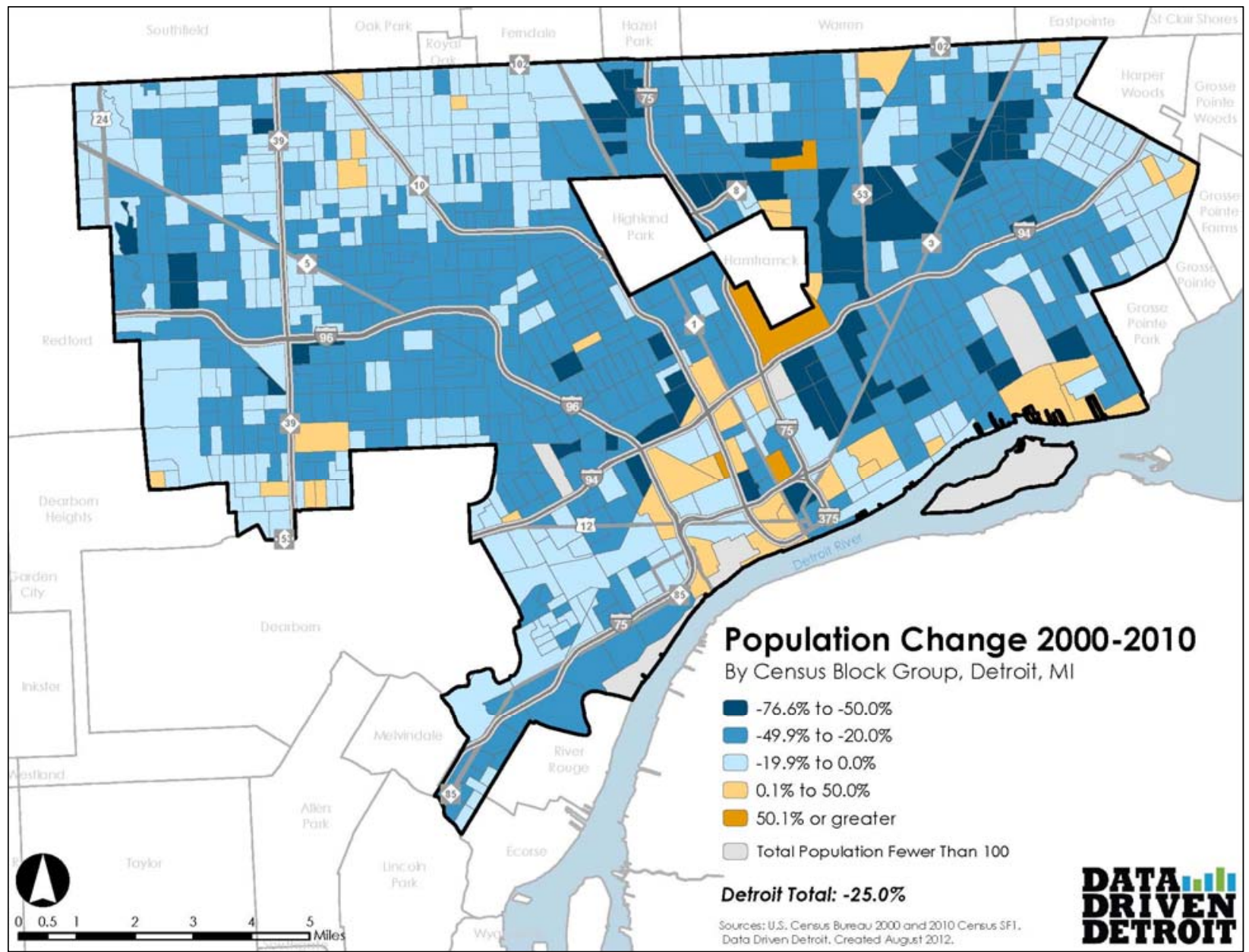

Source: Data Driven Detroit, 2012.

only $14 \%$ of the state's population (U.S. Census Bureau, n.d.-b). The city's unemployment rate is 40 percent and its poverty rate $36 \%$ (U.S. Census Bureau, n.d.-c). Basic needs for urban and social services increasingly go unmet (Bomey \& Gallagher, 2013; Boyle, 2001; Farley, Danziger, \& Holzer, 2000; Galster, 2012; Sugrue, 2005). The 2008 recession exacerbated losses for Detroit's families due to persistent unemployment and housing foreclosures (Kurth, Wilkinson, \& Aguilar, 2013).

Since the 1970s and '80s, the national food sector also became more suburban, global, and

\footnotetext{
${ }^{2}$ Note that SIC codes were replaced by NAICS codes in 1997 with wholesale trade in grocery and related products represented by SIC\# 504 (1967) and NAICS\# 4244 (2012).
}

consolidated, and supermarket redlining contributed to disinvestment, all with the result that many poor urban neighborhoods became systematically disadvantaged (Guptill \& Wilkins, 2002; Hendrickson \& Heffernan, 2007; Morales, 2011; Pothukuchi, 2005; Pothukuchi et al., 2008). Detroit was not immune to these trends. Wholesale trade in grocery and related products in Detroit went from 629 establishments in 1967 doing more than US $\$ 12.4$ billion in sales to 350 establishments in 2012 with sales of US\$8.3 billion (both in 2015 dollars) ${ }^{2}$ (U.S. Census Bureau, 1967, 2012). Smaller

The 1967 data covered the Detroit SMSA (Standard Metropolitan Statistical Area), which included Macomb, Oakland, and Wayne Counties. I derived sales for a 
grocery and specialty stores that relied on wholesalers also were hurt. Many, though not all, of the city's neighborhoods lack decent, full-service grocery stores nearby. As a consequence, lowincome households without cars often rely on complex, expensive, and informal transportation arrangements for the one or two big monthly stocking trips with their SNAP benefits, and on corner stores that offer few healthy, affordable options (Mari Gallagher Research \& Consulting Group, 2007; Pothukuchi, 2008).

The majority of food, convenience, and liquor stores in Detroit are owned by people of Chaldean ancestry - a Christian community that traces its origins to Iraq. Chaldean immigration to the area expanded significantly in the 1980s (Sengstock, n.d.). Here, as elsewhere, such businesses offer new immigrants a chance to gain a cultural and economic foothold in the new country (Aldrich \& Waldinger, 1990; Sanders \& Nee, 1996). Reports of tensions with the city's mostly African American residents, however, are not uncommon (Brooks, 2012; Darden, Hill, Thomas, \& Thomas, 1987; Darden \& Thomas, 2013; Gold, 2010; Meredith, 1999; Min, 2011; Peterson, 1983). Commonly expressed grievances include disrespectful treatment of residents, sales of prohibited goods to minors, and exploitation of residents and the community for profit through the disproportionate sale of unhealthy products (Yakini, 2013).

Previous studies suggest that residents shop for food in neighborhood-based stores, including small convenience stores, liquor stores, and gas stations (Mari Gallagher Research \& Consulting Group, 2007; Pothukuchi, 2005). Except for gas stations, such stores are often called "party stores" because they offer varieties of alcohol even if not all are not self-styled liquor stores. These may carry a variety of packaged foods, beverages including milk, and prepared foods such as pizza, hot dogs, and sandwiches. Many carry vegetables such as potatoes and onions, and fruits such as bananas or apples; gas stations may carry fruits though seldom vegetables. Such stores range in

comparable geography for 2012 by aggregating individual statistics for the three counties, and used the Bureau of Labor size from a couple of hundred square feet in the sales area to several thousand square feet with a wider range of food and non-food selections. Most such stores, including gas stations, are independently operated, even if they are franchises of brand name corporations. These are all considered in this study if an assessment of a particular store documented that residents shop there for food. All are called "corner stores" because they occur at the end of blocks and are within walking distance of their food shoppers, and because the term is commonly used locally.

The typical corner store is partitioned by bullet proof glass into a larger public area and smaller private cabin. Shoppers move about in the public area where packaged foods, beverages such as soda and beer, and other products are arrayed on shelves and in coolers. Store keepers typically stay behind the barrier. This is also where cigarettes, spirits, lottery machines, and highervalue products are stocked. Payment transactions typically happen through a metal tray under the glass; a revolving window facilitates the transfer of products across the barrier. Stores are typically emblazoned on the outside with large letters announcing "liquor," "Lotto," and acceptance of nutrition programs, SNAP (Bridge Card) and WIC (see Image 1).

\section{Research Questions and Methods}

The project used a participatory action research (PAR) methodology to determine if interventions could be developed to sustainably increase the availability and sales of fresh produce in corner stores in impoverished Detroit neighborhoods. PAR is an approach to creating knowledge in a context of practice in which researchers work intentionally and in partnership with practitioners and intended beneficiaries. Unlike traditional social science research, its purpose is not primarily or solely intended to understand social arrangements, but rather to effect desired change as a path to generating knowledge, empowering stakeholders, and enriching democratic possibilities (BradburyHuang, 2010; Gergen, 2003; Mies, 1983; Reason \&

Statistics inflation calculator to derive figures for 2015 at http://data.bls.gov/cgi-bin/cpicalc.pl? 
Bradbury, 2001). In short, it seeks to understand the world by trying to change it, emphasizing principles of collective action, experimentation, and reflection. Such an approach that integrates issues related to implementation with evaluation is atypical in corner store research in which separation of the stages and actors is more common (Karpyn \& BurtonLaurison, 2013).

PAR scholars eschew viewing the practice simply as a specialized set of methods, rather seeing it as emerging in the act of doing it (Reason \& Bradbury, 2001). In keeping with this approach, project decisions were made in three main phases, with each phase developed to obtain change in the desired direction while building on knowledge acquired in the previous one. Decisions and outcomes were carefully documented in each phase. This also meant that what was more of a PAR methodology in Phase I became less participatory in Phase II as project geography expanded incrementally and returned to becoming more participatory in Phase III as new community partners joined depending on the nature of activities and their location. See Appendix for a summary discussion of the three phases, the main questions, methods, findings, and participants and/or partners in each phase.

\footnotetext{
${ }^{3}$ When the project received an external grant in 2009, we decided to create a brand that would be recognizable for residents and activists as a moniker for healthy corner stores. After brainstorming possible names with partners and reviewing existing programs to avoid brand confusion, we settled on Detroit FRESH, with FRESH in caps to denote the emphasis on fresh produce.
}

\section{Detroit FRESH ${ }^{3}$ : Phases of the Action Research}

\section{Phase I (summer 2008-summer 2009): Community dialogues, assessment, initial actions}

Phase I of the project started with informal conversations with one of SEED Wayne's main community partner Capuchin Soup Kitchen's (CSK) staff and guests. ${ }^{4}$ These conversations, which occurred over five sessions each with six to 13 participants in fall 2008, explored participants' experiences with obtaining groceries and healthy food and with the history of food access in the neighborhood. They also elicited notions of effective neighborhood food environments, and concrete changes required to enable neighborhoods to foster greater access to healthy food. The conversations culminated in a community meeting

\footnotetext{
${ }^{4}$ Guests are individuals who come in for a free meal at the soup kitchen. CSK welcomes all to eat at the soup kitchen, no questions asked. Many guests are neighborhood residents, most are single adults, men and women, who visit for food and socializing. Most are unemployed or retired, and some also experience substance addiction issues and/or forms of chronic disability.
} 
later that fall, organized to share and get information and build support for proposed actions. Participants—guests of the soup kitchen, residents from the surrounding neighborhood, and staff of the Earthworks Urban Farm, a project of CSKrecalled the neighborhoods of their youth and food stores that offered a variety of foods, including fresh produce. One participant summed the conversation up thus,

I've been here all my life-I'm 64-and it ain't nothing like it used to be. This neighborhood was full of people and houses. Neighbors looked out for each other and there was a lot of sharing of food. Mom and pop stores were run by folks from the neighborhood. We used to have trucks come by, shouting strawberries, pumpkins and watermelons. Then the families left and grocery stores closed one by one-Thrifty Scot, Farmer Jack, the rest.... The party stores here are all about liquor and cigarettes. The [store owners] don't live in the community....They just want to make a quick buck from us.

These reminiscences were steeped with both nostalgia for neighborhood assets that were lost as well as bitterness for the seeming prevalence of addictions among residents that are fed by the stores. Participants discussed interactions with store owners, and recounted both general disrespect—-such as having to transact through a bulletproof partition — and specifically in personal interactions.

[Store operators] won't say hello or good morning or nothing. They take our money from [behind] the [bulletproof] glass. What we gonna do-shoot them or something? They want our money, but they [are] also afraid of us.

\footnotetext{
${ }^{5}$ University students were involved in a variety of ways in the project. Four led specific tasks as part of two class projects in UP 5430, Cities and Food, winter 2009 and 2010. Projects related to store assessment in Phase I as well as neighborhood outreach in Phase II. Student assistants also were hired as
}

A handful of participants were sufficiently motivated to propose actions they themselves could initiate. One such proposal sought to explore if the corner stores in the neighborhood could be persuaded to offer more fresh produce; another was for a group of residents to organize a mobile farm stand. This project is a report on actions related to the former proposal.

Based on emerging agreements about next steps, in winter 2009, a group of CSK guests and staff, along with a team of students in the Cities and Food class, developed an instrument and undertook a systematic assessment of all stores mapped within a one-mile $(1.6-\mathrm{km})$ radius of the soup kitchen, to explore the availability of fresh produce, and stores' past experiences, if any, with produce. Store operators were also asked if they would be willing to offer fruits and vegetables $(\mathrm{F} \& \mathrm{~V})$ with the project's assistance. ${ }^{5}$ Together, they visited 30 corner stores as defined in this paper, and collected data about store size, products, refrigeration infrastructure, and participation in government nutrition programs such as SNAP and WIC. We connected three stores that agreed to participate to a wholesale produce distributor located about a mile $(1.6 \mathrm{~km})$ away, and equipped them with baskets and other basic supplies. Findings from this phase and others are reported in a following section. Three stores, it turned out, was too small a number to develop a network needed for efficient wholesale distribution. However, it offered some initial lessons and formed the basis for a grant proposal to support continuing work.

\section{Phase II (summer 2009-summer 2012): Project implementation and review \\ With the help of a grant obtained in partnership with CSK, in summer 2009, Detroit FRESH expanded incrementally, block by block, to assess and recruit all corner stores on the east side as well as a few in the near west side. Stores within one quarter mile $(.40 \mathrm{~km})$ of a larger grocery store were}

project staff to implement specific tasks (store and distributor check-ins, neighborhood outreach, and Healthy Food Fairs); about a dozen other students volunteered in neighborhood outreach activities. 
excluded. As of October 2011, 214 stores were assessed and recruited. Of these, only 26 agreed to participate in the project, highlighting the challenge of increasing fresh food access through corner stores.

The recruitment script, refined from Phase I, was one seeking partnership with stores, and contained a mix of moral and pragmatic arguments. Acknowledging their success and resilience in impoverished neighborhoods, we argued to operators that the majority of profits they were able to extract tended to be from products that were less than wholesome-cigarettes, soda, a variety of alcoholic beverages and spirits, and processed foods high in fat, sugar and salt. This dynamic should be balanced if only modestly, the argument went, by the supply of fresh and healthy foods. In other words, stores were making money from an impoverished neighborhood whose residents had few choices; why not provide a positive service in return? The project offered neither financial incentive nor compensation to stores, but rather, assistance related to produce supply and management, marketing, and community outreach. Our intent was that, at the very least, stores should not experience financial losses in supplying produce.

Operators who agreed to participate were supportive of the project's goals, took seriously their role in serving the neighborhood, welcomed the project's assistance in a challenging category that offered little profit, and also welcomed the positive publicity the effort promised. As stores came on board, they received detailed tips on produce selection, management, merchandising, and marketing. They were also connected to one of three wholesale distributors partnering with the project. Finally, they benefitted from regular neighborhood outreach on their behalf, including to community-based organizations operating in the neighborhood. Depending on assessment of store capacity and infrastructure, stores also received basic supplies such as baskets, shelves, scales, and one was given a small refrigerator in which to store produce. Social marketing materials included attractively designed project posters and in-store flyers, and those that were tailored to particular stores that were distributed by project staff in the neighborhood of those stores. Periodic mailings to organizations in the participating store's neighborhood contained project descriptions, updates, and requests for outreach to the organization's members.

The three distributors, which included a mobile (retail) market operating in a smaller part of the project area, agreed to offer wholesale prices for orders that were smaller than a typical wholesale transaction. The two wholesale distributors also agreed to deliver orders to the store without charge, for orders of US $\$ 75$ or more, or a nominal fee for smaller amounts; the mobile market had no such restrictions and even went out of its route to service a project store. Delivery was key to minimizing operator effort; the project sought to mimic how other parts of the store inventory such as soda, beer, and packaged snacks, were replenished. Some corner stores chose to bypass our distributors to purchase caseloads or smaller amounts of produce on their own from suburban superstores; they were asked to share related receipts for our documentation and analysis. After some trial and error, store purchases, rather than customer purchases, formed the basis, along with documentation of wastes, for tracking trends in the movement of produce in the project. However, these were less than reliable for purchases made from sources outside of the three participating distributors. Harried operators found produce related transactions simply too insignificant to their bottom lines, for the demands the project seemed to be making on them.

Soon after a store was equipped with product and related in-store marketing (and periodically from then on) project representatives—student employees and volunteers-went door to door in the surrounding neighborhood, approximately a fifth or sixth of a mile $(.32$ or $.27 \mathrm{~km})$ around the store, to distribute flyers announcing the availability of produce in the store. They also engaged residents in conversations about experiences with the store and types of produce desired there. Documented in project journals, neighborhood canvassing provided valuable contextual information on store-resident relationships, residents' grocery shopping patterns, and also firsthand knowledge of neighborhoods, many of which were experiencing visible distress in 2009-2011, when 
significant fieldwork occurred. Store check-in visits occurred monthly (or more or less frequently depending on the store's needs and status) to record produce quality and price, collect receipts, and troubleshoot. Check-in reports led to adjustments based on that and other stores' experiences. These are summarized in the next section.

Social marketing was not without its problems. Regular neighborhood outreach, which took some effort in coordinating volunteers and organizing rides and which was found to be effective in increasing sales, fell out of sync when stores delayed restocking. Outreach to churches and other neighborhood organizations revealed their leaders' ambivalence to stores selling primarily liquor and cigarettes and stores that were not otherwise considered good neighbors. Many organizations were shuttered during daytime hours of visit, or failed to respond to calls or materials mailed to them. As noted before, the project was implemented at the peak of the Great Recession; organizations also were feeling its brunt.

The factors that contributed to successes and challenges in the experiences of stores in this phase are reported in a following section. However, the challenges experienced by stores underscored the

\section{Image 2. Healthy Food Fair Staff Use Motivational Interviews to Engage Residents in Conversations About Healthy Diets}

In the background, youth chefs from Earthworks Urban Farm demonstrate a fresh salsa assembled and eaten with products available in the partnering corner store across the street.

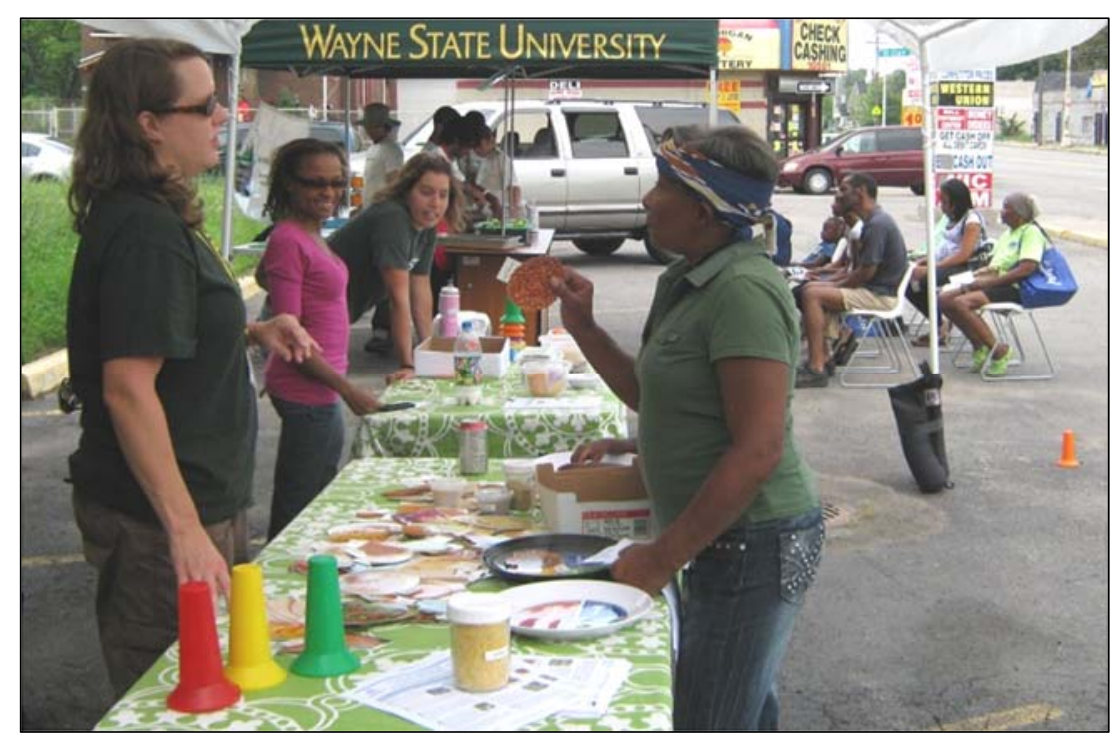

need to attend to broader neighborhood dynamics including residents' relationship to the stores. Given the relatively small inventories of produce and high prices in corner stores, it made little sense for any shopper to buy large amounts of groceries here even if stores were consistent in their supply. Thus, we had to review possibilities for fresh produce in corner stores in terms of what and how much residents realistically would buy, and possibilities for residents to increase their fruit and vegetable consumption without incurring higher costs themselves. Additionally, store owners were expressing urgency with falling overall sales. In conversations with store owners to discuss findings from Phase II, the idea of the Healthy Food Fairs (HFF) was born. Implemented first in summer 2011, HFFs served multiple purposes: to better link stores and residents around healthy diets with more fresh produce, better understand residents' grocery shopping patterns and the role of corner stores in these patterns, and offer nutrition resources to encourage $F \& V$ consumption.

\section{Phase III (summer 2011-summer 2012): Broadening and intensifying; Healthy Food Fairs}

The third phase continued activities started in the previous one, but ceased further store assessment and recruitment until we were better able to gauge why some were successful and what challenged others given several months of experience, and to outline future steps such as Healthy Food Fairs. Stores that were enthusiastic partners early on were also interested in partnering in HFFs. Because these stores also had a relatively longer term and positive relationship with their shoppers and carried a broader range of groceries, the project offered two fairs in 2011 as a test; HFFs were organized in stores' parking lots (see Image 2).

With the help of food image cutouts and posters, staff 
used motivational interviews (Miller \& Rose, 2009) to have participants-residents of store neighborhoods and passersby-reflect on their diets and how to make incremental low-cost improvements especially with fresh F\&V. HFFs also included games and other interactive activities for youth, and food demos with healthy, conveniently assembled recipes featuring products available in partnering corner stores. Finally, we surveyed participants about their grocery shopping in general and nature of shopping at the corner store. Feedback regarding the HFFs from residents and store owners was extremely positive and insightful so much so that HFFs became a significant activity for SEED Wayne in the years that followed, quite separate from the corner store effort. Project staff members - mostly university students — and store owners were enthusiastic about HFFs given the immediate, positive responses and F\&V (and other healthy food) sales the fairs generated. The following year saw six fairs, three of which were in partnership with stores and three others with neighborhood organizations in areas with several participating stores.

HFF surveys of 162 residents in the neighborhoods of five corner stores confirmed qualitative data obtained from informal conversations logged during neighborhood canvassing. During this phase, we added messaging related to healthy snacking in the stores- "Choose an apple instead of a bag of chips" - and intentionally engaged more young people in HFFs given their snack purchases at the stores. We also engaged youth "chefs" from Earthworks Urban Farm's Youth Farm Stand Project to offer a food demo at one HFF. Participants were not unreceptive to the message and received the youth chefs enthusiastically, but shifting over the long term from highly processed sugary and savory snacks to fresh fruits is no small challenge. It requires combining education, consistent messaging and sustained support (Waterlander, deBoer, Schuit, Seidell, \& Steenhuis, 2013). Low-income households already spend less per capita per week on fruits and vegetables than their higher income counterparts (Blisard, Stewart, \& Jolliffe, 2004). For the change to be supported by corner stores, it would require even more effort to ensure regular availability, higher quality, and more attractive pricing of fruit and vegetable snacks than is available in the typical corner store.

\section{Findings}

The vast majority of the 30 stores assessed in Phase I had little to no produce. Where produce was present, only a few choices such as potatoes, onions, and bananas were available, with just a couple of stores offering more items, such as tomatoes, yams, lettuce, and grapes. Quality nearly everywhere tended to be low and unit prices predictably much higher than in larger supermarkets. Almost all stores-27-refused to participate in the project, with the most common reason being that fresh produce was not part of their business model. Stores blamed diminishing sales for discontinuing produce from their inventory in the past. A few offered produce in warmer months when demand increased for corn, fresh greens, and such favorites as watermelon and cantaloupe. Many who declined to participate, nonetheless, expressed an interest in joining the project if conditions improved. Others asked if they would be reimbursed for wastes resulting from unsold product. These findings were echoed as the project's geography expanded, as described in Phase II.

Of the 26 stores that joined as of Phase II, nine were convenience grocery stores in that they carried more categories of groceries than just packaged snacks; three were gas stations, and the rest were mostly liquor or dollar stores. All were recruited for the project because they sold a variety of foods to surrounding residents. Three stores were owned by African-Americans; of the rest, all but one of the owners were of Chaldean ancestry. Ten stores were $2,000 \mathrm{ft}^{2}\left(185 \mathrm{~m}^{2}\right)$ or smaller, another 10 between 2,000 and 4,000 $\mathrm{ft}^{2}\left(371 \mathrm{~m}^{2}\right)$, and six were $4,000 \mathrm{ft}^{2}$ or larger. Only one was larger than $6,000 \mathrm{ft}^{2}\left(557 \mathrm{~m}^{2}\right)$ at $12,000 \mathrm{ft}^{2}(1115$ $\left.\mathrm{m}^{2}\right)$. Eleven stores carried no fresh produce at all at the time of the initial assessment. Others carried only fruits (mostly bananas) or F\&V in two or three varieties each, with the most common vegetables being potatoes and onions. Twenty-four accepted SNAP, or the Bridge Card, and 18 accepted WIC benefits.

Although store produce purchase receipts were 
received less than consistently, from available data, average $\mathrm{F} \& \mathrm{~V}$ orders across stores were US $\$ 88$ per month, with a low of about US $\$ 27$ for fruits at a gas station and high of nearly US $\$ 200$ for a corner grocery store. For some perspective on wholesale prices, a standard case of Macintosh apples contained about 80 apples and cost US $\$ 40$ during the time of the research. A $40 \mathrm{lb}$. (18.1 kg) carton of bananas cost US $\$ 20$; a carton of 24 heads of lettuce, US\$18; and a $25 \mathrm{lb}$. (11.3 kg) carton of tomatoes, about US $\$ 17$. Those who worked with our wholesale distributors tended to order once a month to take advantage of free delivery; others, including those who purchased from the mobile market purchased smaller quantities as needed. These data underscore the relatively small scale of produce supply that corner stores in the study feasibly offered.

After joining the project, seven stores more than doubled their initial inventory both in terms of $F \& V$ varieties as well as quantities offered (two others - the liquor store and one gas stationstarted from zero). Nonetheless, even these stores were continually experimenting with inventory and timing of orders so as to minimize wastes while increasing or stabilizing sales. Six stores reported significant increases in sales - of an average of $22 \%{ }^{6}$ —in the three days immediately following the first round of neighborhood outreach; more noted acknowledgement and praise from community members and smaller sales increments.

According to one corner store owner, for example, a shopper who came by "only once in a great while" stopped by more often to shop at the store, "as if to support us deliberately, even though she was not always buying fresh produce. The first time she saw all these baskets [of produce], she said, "Wow, you are starting to care about us."' This, and similar initial reactions, generated such

\footnotetext{
${ }^{6}$ Stores were connected with produce dealers soon after they came on board, typically early in the month. Community canvassing followed a month or so after the store started stocking, and glitches were worked out. Thus, we commenced canvassing for a store at different points in a calendar year. Although no stocking and canvassing occurred between December and February, the difference in sales following canvassing in some stores partially might be explained by the season when data were gathered. For example, the post-
}

pride that operators often went out of their way to carry produce in subsequent months. This operator's fears about wastes also waned. "I just take the bananas and tomatoes that are going soft home with me. I am eating more fruits and vegetables," he said with a wink.

Only 19 stores remained with the program at the end of summer 2012 (see Map 2). Of these, only 9 supplied fresh produce consistently based on field logs, although supplies were meager in practically every store towards the end of the month and in the depth of winter (see table in the Appendix). Three stores that dropped out of the program were unable to overcome difficulties associated with fresh produce or were frustrated by project requirements, two sold the store to operators who were disinterested in the project, and two closed the store altogether. Inventory also suffered when illness or other priorities delayed orders or restocking visits to larger stores.

Despite increased sales initially, many stores wavered in their participation due to the effortincluding availability of personnel, time, and knowledge-required to manage fresh produce, the scant difference it made to their bottom line, and the general decline in overall sales as the project progressed. This included four stores that had WIC agreements with the state, which required them to stock at least two types of fresh fruits and two of fresh vegetables, not including potatoes. Stores typically restocked after a prompt from us prior to a scheduled neighborhood canvassing trip or waited for the start of the month before ordering. Thus, despite initial successes, too many factors militated against the cycle becoming self-sustaining.

\section{Factors in Effective Store Participation}

In this small sample of participating stores, neighborhood and store factors are implicated in

canvassing increase in sales in early May might be partially explained by the warmer weather relative to the previous month's baseline sales. Similarly, canvassing may have had a differential impact depending on exactly when it fell relative to a weekend. Canvassing typically occurred only on weekdays and Saturdays. Because our interests were more programmatic rather than research-related we did not track these effects closely for the same store or between stores. 
Map 2. Detroit FRESH Participating and Nonparticipating Stores by Census Tract, as of August 2012

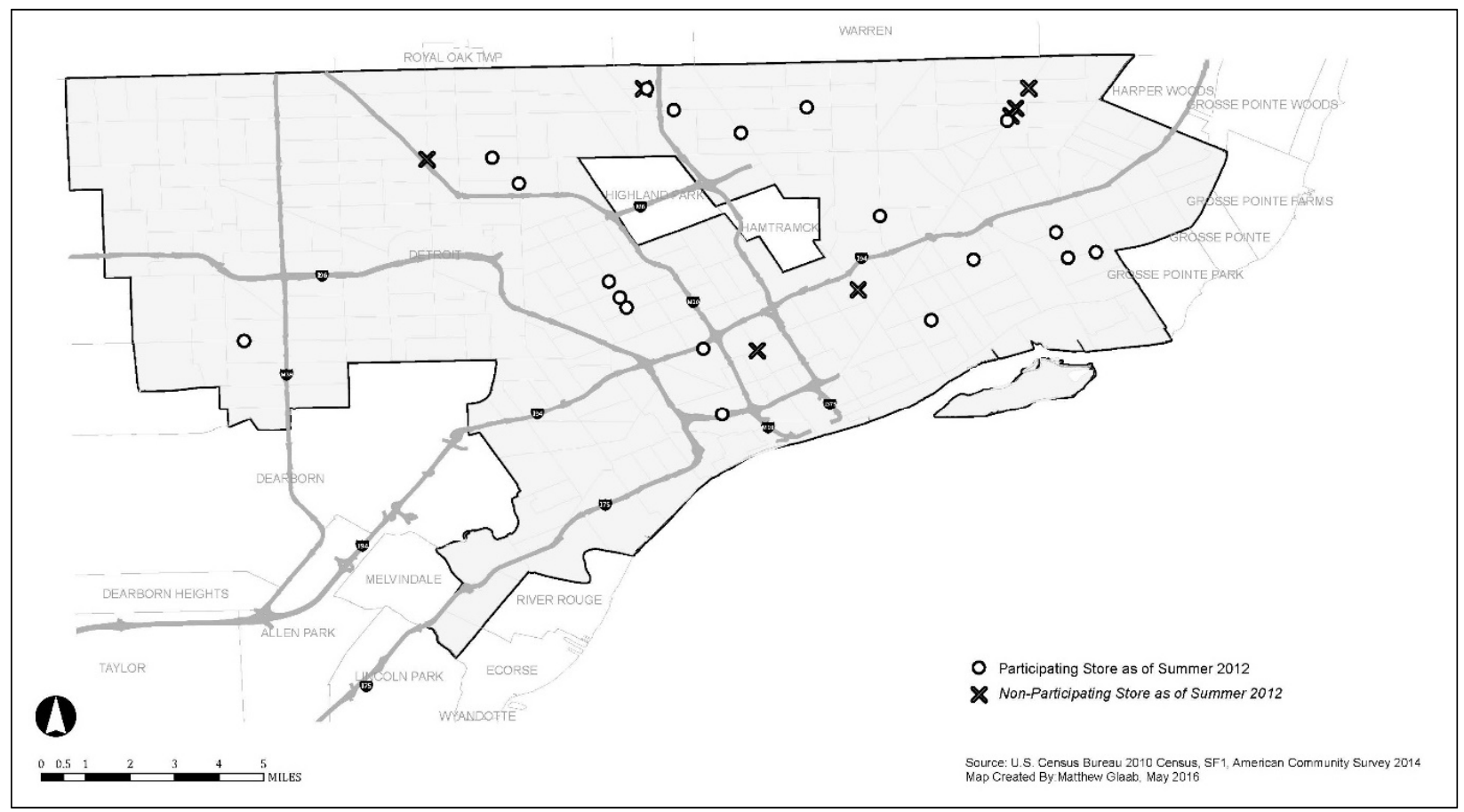

store performance in the project (see Table 1). Shopper and distributor factors are also important. Unsurprisingly, a majority of stores that opted out of the program prematurely and those that were inconsistent in their supply were in zip codes that lost population at higher rates than the city as a whole between 2000 and 2010. Admittedly, zip codes are a much larger geography than the effective market area of most stores but they offer a view to which operators were also attending, as documented in check-in reports. On a finer level, as Map 3 shows, all project stores had at least one abutting census tract that lost population between 2000 and 2010. Because we did not document the exact market area for each store, it is impossible to know the exact effect census tract-level trends had on stores; we relied mostly on operator accounts of their business trends.

Also expectedly, a majority of the consistently high performing stores (five of nine) were in zip codes that lost population at lower rates than the city's average percent of loss. That four similarly high-performing stores existed in zip codes that lost more population than the city's average needs explanation. One such store saw a reduction in competition as three nearby stores closed down; two were gas stations that carried only fruit, which was popular with drivers and pedestrian residents alike. Thus while neighborhood decline factored in stores' reluctance to stay in the project or participate consistently, the actual effects for a particular store are more nuanced.

Table 1. Store Performance Relative to Population Loss Between 2000 and 2010 in Zip Codes Relative to the City as a Whole, $N=26$

\begin{tabular}{lccc}
\hline $\begin{array}{l}\text { Rate of population loss (2000- } \\
\text { 2010) in the zip code relative to } \\
\text { the city as a whole }\end{array}$ & $\begin{array}{c}\text { Stores leaving the } \\
\text { program prematurely }\end{array}$ & $\begin{array}{c}\text { Stores performing } \\
\text { inconsistently }\end{array}$ & $\begin{array}{c}\text { Stores performing } \\
\text { consistently }\end{array}$ \\
\hline Higher rate of loss & $5(19 \%)$ & $7(27 \%)$ & $4(15 \%)$ \\
\hline Lower rate of loss & $2(8 \%)$ & $3(12 \%)$ & $5(19 \%)$ \\
\hline
\end{tabular}

Population data source: U.S. Census Bureau, n.d.-b. 


\section{Map 3. Population Change (2000-2010) in Detroit FRESH Member Neighborhoods, by Census Tract} Both participating and nonparticipating stores, as of August 2012, are shown.

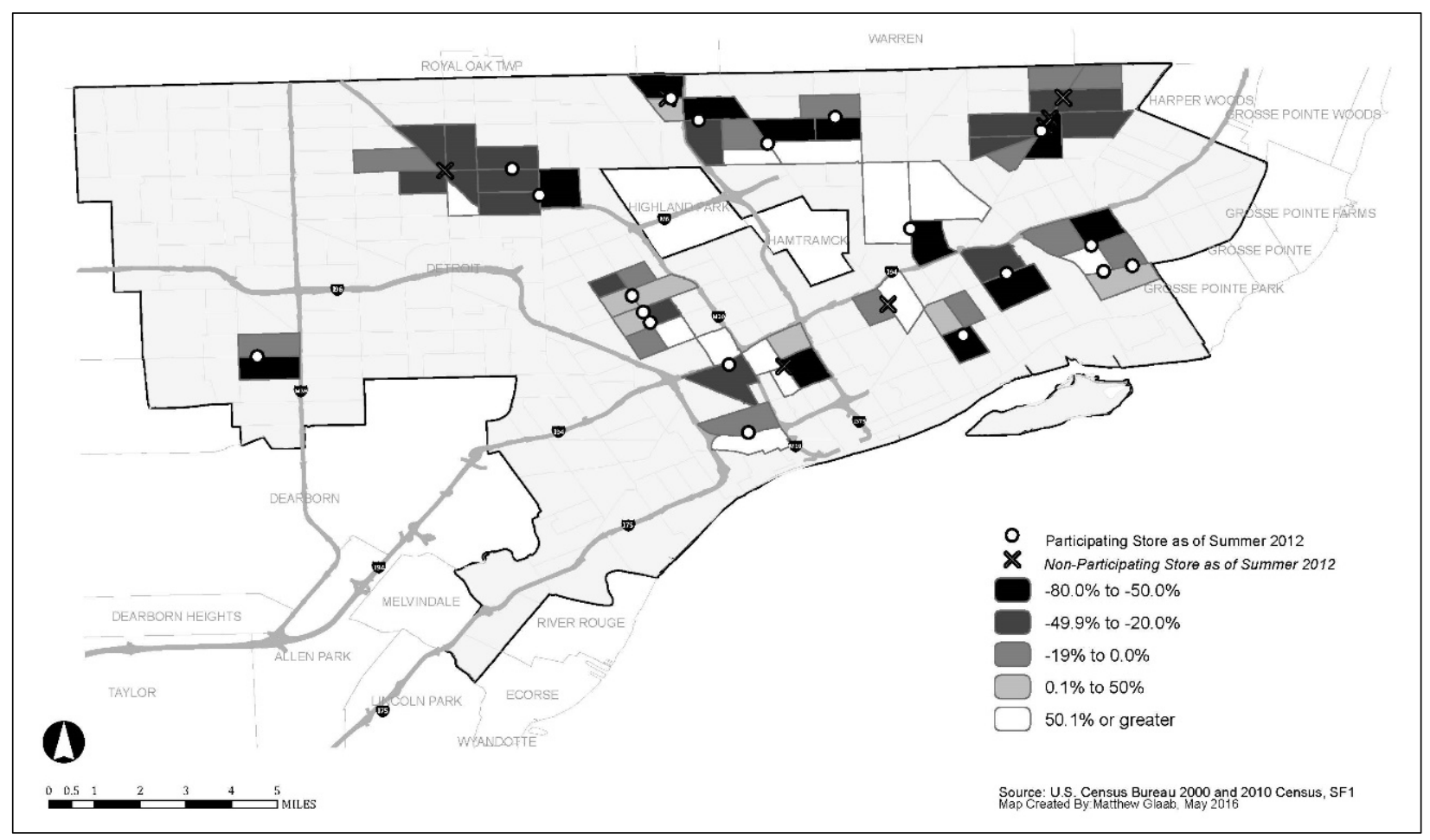

Store operators with previous experience with fresh produce and commitment to their neighborhoods did better than others. These stores also tended to have larger footprints than purely liquor and/or party stores and carried a broader range of groceries including dry goods. Offering a deli was advantageous in three cases, as vegetables were incorporated in deli offerings (such as chili) before they went bad, thereby minimizing waste. Operator commitment to the project and their persistence during the time it took for community outreach to register in the form of higher sales was especially crucial. Such operators made more shelf and cooler space available for produce, merchandized it attractively, priced it competitively, and generally managed it better. They were also willing to experiment with ways to increase sales and were more responsive to related shopper requests. Such operators typically had a longer history in their neighborhoods and knew their customers well, and took pride in serving them. Unlike in other stores where the check-out transaction was strictly business, conversations with customers in these stores tended to be longer, more wide-ranging, and personal in nature, from our store-based observations.

Distribution issues worked out more smoothly for stores placing larger orders and those placing orders more consistently than others. The mobile market obtained inconsistent business, but some store owners complained that the mobile van itself was unreliable for schedule and inventory. All this underscores the tenuous nature of coordinating multiple moving parts to create the semblance of a system, each part of which, by itself, is quite fragile given its own experience of urban stressors. Riskaverse strategies such as sourcing from the outside resulted in quantities too small, frustrating some residents who came to the store following neighborhood outreach, only to find some products already sold out. Stores that were more or less liquor stores with mostly packaged foods were both less motivated and less capable, even if they participated out of a hope of boosting flagging overall sales. Because shoppers were less accustomed to buying fresh foods there, such stores may 
not be worth the effort in future projects to develop supply mechanisms and conduct related neighborhood outreach. Gas stations' success with fruit was both surprising and gratifying, suggesting the need for further exploration of such outlets to benefit walk-in traffic of mostly nearby residents.

The produce supply and demand dynamic in the project made clear that quantities, variety, and pricing even in the highest performing corner stores simply could not support significant produce purchases by households. Phase III's efforts therefore sought to shift expenditures on snacks in these stores from mostly soda and packaged foods to fresh fruits, given the not insignificant portions of Bridge Card (SNAP) spending that occurred. This spending was confirmed by responses to 162 surveys conducted at five Healthy Food Fairs.

It is beyond the scope of this paper to detail the survey method, respondents, responses and limitations. To summarize, the vast majority of respondents $(92 \%)$ reported doing the bulk of their monthly grocery shopping in larger chain and independently-owned supermarkets outside the neighborhood and even the city, including produce purchases at Eastern Market, the region's largest produce market, and produce stores such as Randazzo's. A majority also used SNAP benefits for their food shopping, including in corner stores. Trips to the corner store tended to be for top-up needs or perishables such as bread, milk, or F\&V in relatively small quantities, and snacks such as cookies, chips, and soda. Most indicated willingness to buy more produce at their corner store if varieties and quantities were increased and prices lowered, echoing findings elsewhere (Bodor, Rose, Farley, Swalm, \& Scott, 2008; Martin et al., 2012). Without much higher subsidy, this is infeasible given overall store business models and, in this context, shrinking overall sales. A smaller majority-58\%—indicated visiting the corner store once a week or more often, although it is unclear how many of these visits were intended for, or included, purchases of food (as opposed to cigarettes, alcohol, or lottery).

\section{Reflections and Recommendations}

Our action research sought to explore questions raised by Karpyn and Burton-Laurison (2013) about corner store initiatives, as they relate to financing, distribution, marketing, and collaboration. The project's key objectives were to gain a deeper understanding of how elements of the food system worked (or did not work) in the present context, and if they could be re-assembled in new ways so as to sustainably offer fresh produce within Detroit's poorest neighborhoods. And if the effort succeeded, could specific factors be identified and replicated? Could challenges be overcome? By seeking to answer these specific questions through systematically developed actions in three phases, participants moved from assessing and recruiting corner stores, to inquiring into residents' relationship with corner stores for their grocery shopping, to emphasizing healthy snacking with fruits and vegetables.

As lessons were shared in each phase, participants gained significant knowledge about the needs, aspirations, and daily struggles of others: residents, store operators, wholesalers, students, and food activists. While some findings were depressing, inspiring stories and people also emerged. For example, given stories of disrespect experienced by residents in corner stores, participants were pleasantly surprised to find operators who were respectful and responsive to, and wellliked by, their customers. Such operators taught us about the everyday business, supply chain, and regulatory constraints that they confronted, and their often complicated relationships with the community. When asked why he decided against erecting the bullet-proof barrier common to corner stores, for example, one longtime operator sniffed:

And what good will that do...? If someone comes in with a gun and wants something, they can point [the gun] at a shopper nearby and we will give them whatever they want, anything. We know all the neighbors here, they depend on us. If they get hurt, we get hurt. We are all in the same boat.

Students offered similar insights. One wrote about her neighborhood canvassing:

When we talk about food access in Detroit, the picture is often drawn in black and 
white, sometimes literally, given the racial dynamic, and people are like stick figures. Residents are victims and the corner store owners are exploiters. I have no doubt that these are realities [more generally]. [However,] I now see the neighborhoods and stores as real places, with people working hard and struggling and hustling. I see storekeepers as human, some quite decent and thoughtful about their business relationships with neighbors. Not all, but enough to give me hope.

On the flip side, canvassing students also recorded disdain for the project's goals and resentment of its scrutiny of store practices. In one $\log$, a student wrote

We found a decent supply of various produce but which needed to be set out....A bag of potatoes had a price tag of US\$0.69 which, at first glance, I thought was cheap, cheaper even than in larger supermarkets. Then I realized that the price was for a single potato. When I mentioned to [name of operator] that US $\$ 0.69$ per potato in a store seemed steep, he said, "You all are trying too hard."

Who were we to raise questions, the storekeeper seemed to ask, if residents were willing to pay such high prices.

Students were also deeply affected by the deteriorating conditions in some neighborhoods even in the short timeframe of the project. One log in summer 2012, for example, noted a pleasant conversation with an elderly couple sitting on the porch of a house with stained-glass windows. This house was found burned down when staff returned three months later. Furthermore, students encountered suspicion from residents in neighborhoods that typically received few outsiders; one even came out to yell at them to "get the hell out the neighborhood." Such experiences, though eyeopening, left students disheartened and were the subject of much debriefing in project meetings. Thus the study's lessons went far beyond corner store and food supply dynamics and offered insights into residents' perspectives and neighborhood dynamics.

Lacking economies of scale and due to other internal and external constraints, corner stores have only limited ability, in the best of times, to offer produce in desired quantities, varieties, and prices without subsidy or increased demand. These, however, are hardly the best of times for Detroit's poorest neighborhoods. As neighborhoods became even more depopulated, stores were less able to cope. Thus, our assumption of stores' resilience in the face of decline found its limits. Many project stores performed only lethargically as sales declined. Some quit the project altogether and a handful shut down operations soon afterwards. Surprisingly, however, even in depopulating neighborhoods, a few stores continued to offer produce more or less effectively. Perhaps it is only a matter of time before they, too, feel the pinch and cut back or shut down. With successful urban agriculture and farm stand initiatives in many Detroit neighborhoods, corner stores may be suboptimal targets for increasing access to fresh and healthy food.

Nonetheless, as year-round sources, many corner stores could serve their neighborhoods better than they do now. They could also be better supported than was possible in this test project. Following are a few specific recommendations: One, current agreements related to the WIC program's produce stocking requirements that corner stores sign should be enforced by the state. Such stores could also be supported to offer nutrition education materials through partnerships with health and food security organizations. Two, because fresh produce is seldom a profitable category, stores that are good neighbors according to this project's criteria preferentially could be awarded grants and other support by agencies such as the Detroit Economic Growth Corporation. Such stores could also be assisted with relocation if and when city restructuring plans are implemented.

Three, as a longer term strategy, licenses to sell liquor, tobacco products, and lottery, all of which constitute significant earnings for stores, could be linked to a minimal healthy and fresh food inventory, with associated training and neighborhood partnerships. Regular availability and greater 
varieties of produce within neighborhoods would enable residents to adapt their shopping accordingly and create higher impacts when combined with other strategies. Four, a fresh and/or healthy food distribution system to service corner stores and gas stations is needed, such as by extending the food hub efforts undertaken by Eastern Market Corporation. Such an effort could start with more effective corner stores to test combinations of produce availability, price reductions or incentives, ${ }^{7}$ and nutrition and food demos, all of which are offered by programs in Detroit. Finally, more research is needed. We need to know more about decisions to purchase fruits and vegetables and about food expenditures in corner stores made by low-income residents in this community. Accounting more closely for the differences in the performance of similar stores in neighborhoods facing similar dynamics of abandonment, also merits closer examination so that incentives could be targeted more precisely.

\section{Conclusion}

Detroit's current retail grocery environmentincluding corner stores - is a product of decades of economic and social abandonment and racial discrimination. Place-based efforts to craft an alternative food system have shown to be successful in urban agriculture and even neighborhood farmers markets. However, developing year-round produce supply in neighborhoods, with available neighborhood infrastructure, requires links to elements that are more deeply embedded in the conventional food system-corner stores and produce wholesalers - even if they themselves are marginal in that system. For such projects to effectively deliver produce year-round, bridging the gap between affordability for customers and profitability for the business will require greater subsidy than do other community food efforts. Thus, enabling corner stores to be better

\footnotetext{
${ }^{7}$ Redemption rates in Detroit's neighborhood farmers markets for the Double Up Food Bucks (DUFB), a farmers market incentive program, are reasonably high for neighborhood markets (about 88\%), suggesting that low-income households will take up subsidies for fresh produce. DUFB tokens match SNAP spending at farmers markets (up to US\$20/day) and may be used exclusively on Michigan-sourced fresh fruits and
}

neighbors is scarcely an effort to be relegated to neighborhood collaborations, no matter how competent or resourceful they may be.

\section{References}

Agyeman, J., \& Evans, B. (2004). 'Just sustainability': The emerging discourse of environmental justice in Britain? The Geographical Journal, 170(2), 155-164. https://doi.org/10.1111/j.0016-7398.2004.00117.x

Aldrich, H. E., \& Waldinger, R. (1990). Ethnicity and entrepreneurship. Annual Review of Sociology, 16, 111135. https://doi.org/10.1146/annurev.so.16.0801 $\underline{90.000551}$

Algert, S. J., Agrawal, A., \& Lewis, D. S. (2006). Disparities in access to fresh produce in lowincome neighborhoods in Los Angeles. American Journal of Preventive Medicine, 30(5), 365-370. https://doi.org/10.1016/j.amepre.2006.01.009

Alwitt, L. F., \& Donley, T. D. (1997). Retail stores in poor urban neighborhoods. Journal of Consumer Affairs, 31(1), 139-164. https://doi.org/10.1111/ j.1745-6606.1997.tb00830.x

Andreyeva, T., Blumenthal, D. M., Schwartz, M. B., Long, M. W., \& Brownell, K. D. (2008). Availability and prices of foods across stores and neighborhoods: The case of New Haven, Connecticut. Health Affairs, 27(5), 1381-1388. https://doi.org/10.1377/hlthaff.27.5.1381

Bader, M. D. M., Schwartz-Soicher, O., Jack, D., Weiss, C. C., Richards, C. A., Quinn, J. W.,...Rundle, A. G. (2013). More neighborhood retail associated with lower obesity among New York City public high school students. Health and Place, 23, 104-110. https://doi.org/10.1016/i.healthplace.2013.05.005

Berry, M. F. (Ed.). (1998). Racial and ethnic tensions in American communities: Poverty, inequality and discrimination--Los Angeles hearing. Darby, Pennsylvania: Diane Publishing Co.

Blisard, N., Stewart, H., \& Jolliffe, D. (2004). Low-income households' expenditures on fruits and vegetables (USDA Agricultural Economic Report Number 833). Available from http://purl.umn.edu/34041

vegetables. Wayne State University Farmers Market, which also offers nutrition tabling and food demos, saw a DUFB redemption rate of $95 \%$, suggesting the effectiveness of combining supply with demand-side incentives, educational materials and/or conversations, and healthy food demonstrations. 
Block, D., \& Kouba, J. (2006). A comparison of the availability and affordability of a market basket in two communities in the Chicago area. Public Health Nutrition, 9(7), 837-845. https://doi.org/10.1017/PHN2005924

Block, J. P., Scribner, R. A., \& DeSalvo, K. B. (2004). Fast food, race/ethnicity, and income: A geographic analysis. American Journal of Preventive Medicine, 27(3), 211-217. https://doi.org/10.1016/j.amepre.2004.06.007

Bodor, J. N., Rose, D., Farley, T. A., Swalm, C., \& Scott, S. K. (2008). Neighborhood fruit and vegetable availability and consumption: The role of small food stores in an urban environment. Public Health Nutrition, 11(4), 413-420. https://doi.org/10.1017/S1368980007000493

Bomey, N., \& Gallagher, J. (2013, September 15). How Detroit went broke: The answers may surprise you — and don't blame Coleman Young. Detroit Free Press. Retrieved from http://www.freep.com/ story/news/local/michigan/detroit/2013/09/15/ how-detroit-went-broke-the-answers-may-surpriseyou-and/77152028/

Boyle, K. (2001). The ruins of Detroit: Exploring the urban crisis in the Motor City. Michigan Historical Review, 27(1), 109-127. https://doi.org/10.2307/20173897

Bradbury-Huang, H. (2010). What is good action research?: Why the resurgent interest? Action Research, 8(1), 93-109. https://doi.org/10.1177/1476750310362435

Brooks, J. C. (2012, December 27). Detroit store owner puts black customers on Instagram with racist captions. EurThisNThat. Retrieved February 17, 2016, from http://www.eurthisnthat.com/ 2012/12/27/detroit-store-owner-puts-blackcustomers-on-instagram-with-racist-captions/

Cavanaugh, E., Mallya, G., Brensinger, C., Tierney, A., \& Glanz, K. (2013). Nutrition environments in corner stores in Philadelphia. Preventive Medicine, 56(2), 149-151. https://doi.org/10.1016/i.ypmed.2012.12.007

Cho, S. K. (1993). Korean Americans vs. African Americans: Conflict and construction. In R. Gooding-Williams (Ed.), Reading Rodney King/reading urban uprising (pp. 196-211). New York: Routledge.
Dannefer, R., Williams, D., Baronberg, S. B., \& Silver, L. (2012). Healthy bodegas: Increasing and promoting healthy foods at corner stores in New York City. American Journal of Public Health, 102(10), e27-e31. https://doi.org/10.2105/AJPH.2011.300615

Darden, J. T., Hill, R. C., Thomas, J., \& Thomas, R. (1987). Detroit: Race and uneven development. Philadelphia, Pennsylvania: Temple University Press.

Darden, J. T., \& Thomas, R. W. (2013). Detroit: Race riots, racial conflicts, and efforts to bridge the racial divide. East Lansing, Michigan: MSU Press.

Eckert, J., \& Shetty, S. (2011). Food systems, planning and quantifying access: Using GIS to plan for food retail. Applied Geography, 31(4), 1216-1223. https://doi.org/10.1016/j.apgeog.2011.01.011

Farley, R., Danziger, S. H., \& Holzer, H. J. (2000). Detroit divided. New York: Russell Sage Foundation.

Fisher, M. (Guest Host). (2012, April 9). Asian-owned businesses and community tension in Washington [Radio broadcast]. In K. Nnamdi (Host and Staff), The Kojo Nnamdi Show. Washington, D.C.: WAMU 88.5.

Ford, P. B., \& Dzewaltowski, D. A. (2010). Limited supermarket availability is not associated with obesity risk among participants in the Kansas WIC program. Obesity, 18(10), 1944-1951.

https://doi.org/10.1038/oby.2009.487

Franco, M., Diez Roux, A. V., Glass, T. A., Caballero, B., \& Brancati, F. L. (2008). Neighborhood characteristics and availability of healthy foods in Baltimore. American Journal of Preventive Medicine, 35(6), 561-567. https://doi.org/10.1016/j.amepre.2008.07.003

Galster, G. (2012). Driving Detroit: The quest for respect in the motor city. Philadelphia, Pennsylvania: University of Pennsylvania Press. https://doi.org/10.9783/9780812206463

Galvez, M. P., Morland, K., Raines, C., Kobil, J., Siskind, J., Godbold, J., \& Brenner, B. (2008). Race and food store availability in an inner-city neighbourhood. Public Health Nutrition, 11(6), 624-631. https://doi.org/10.1017/S1368980007001097

Gergen, K. J. (2003). Action research and orders of democracy. Action Research, 1(1), 39-56. https://doi.org/10.1177/14767503030011004 
Gittelsohn, J., Franceschini, M. C. T., Rasooly, I. R., Ries, A. V., Ho, L. S., Pavlovich, W.,...Frick, K. D. (2008). Understanding the food environment in a low-income urban setting: Implications for food store interventions. Journal of Hunger and Environmental Nutrition, 2(2-3), 33-50. https://doi.org/10.1080/19320240801891438

Gittelsohn J., Rowan, M., \& Gadhoke, P. (2012). Interventions in small food stores to change the food environment, improve diet, and reduce risk of chronic disease. Preventing Chronic Disease, 9. https://doi.org/10.5888/pcd9.110015

Gittelsohn, J., Suratkar, S., Song, H.-J., Sacher, S., Rajan, R., Rasooly, I. R.,...Anliker, J. A. (2010). Process evaluation of Baltimore Healthy Stores: A pilot health intervention program with supermarkets and corner stores in Baltimore City. Health Promotion Practice, 11(5), 723-732. https://doi.org/10.1177/1524839908329118

Gold, S. J. (2010). The store in the hood: A century of ethnic business and conflict. Rowman \& Lanham, Maryland: Littlefield Publishers.

Guptill, A., \& Wilkins, J. L. (2002). Buying into the food system: Trends in food retailing in the US and implications for local foods. Agriculture and Human Values, 19(1), 39-51. https://doi.org/10.1023/A:1015024827047

Guthman, J. (2013). Too much food and too little sidewalk? Problematizing the obesogenic environment thesis. Environment and Planning A, 45(1), 142-158. http://journals.sagepub.com/home/epn

Hendrickson, D., Smith, C., \& Eikenberry, N. (2006). Fruit and vegetable access in four low-income food deserts communities in Minnesota. Agriculture and Human V alues, 23(3), 371-383. https://doi.org/10.1007/s10460-006-9002-8

Hendrickson, M., \& Heffernan, W. (2007). Concentration of agricultural markets. Retrieved December 15, 2013, from www.foodcircles.missouri.edu/07contable.pdf

Horowitz, C. R., Colson, K. A., Hebert, P. L., \& Lancaster, K. (2004). Barriers to buying healthy foods for people with diabetes: Evidence of environmental disparities. American Journal of Public Health, 94(9), 1549-1554. https://doi.org/10.2105/AJPH.94.9.1549

Karpyn, A., \& Burton-Laurison, H. (2013). Rethinking research: Creating a practice-based agenda for sustainable small-scale healthy food retail. Journal of Agriculture, Food Systems, and Community Development, 3(4), 139-143. http://dx.doi.org/10.5304/jafscd.2013.034.015

Kaufman, C. J., \& Hernandez, S. A. (1991). The role of the bodega in a US Puerto Rican community. Journal of Retailing, 67(4), 375-397.

Kurth, J., Wilkinson, M., \& Aguilar, L. (2013, October 4). Six decades in Detroit: How abandonment, racial tensions, and financial missteps bankrupted the city. The Detroit News.

LeDoux, T. F,, \& Vojnovic, I. (2013). Going outside the neighborhood: The shopping patterns and adaptations of disadvantaged consumers living in the lower east side neighborhoods of Detroit, Michigan. Health \& Place, 19, 1-14. https://doi.org/10.1016/j.healthplace.2012.09.010

Lucan, S. C., Karpyn, A., \& Sherman, S. (2010). Storing empty calories and chronic disease risk: Snack-food products, nutritive content, and manufacturers in Philadelphia corner stores. Journal of Urban Health, 87(ㄱ), 394-409. https://doi.org/10.1007/s11524010-9453-5

Mari Gallagher Research \& Consulting Group. (2007). Examining the impact of food deserts on public health in Detroit. Available from http://www.uconnrudd center.org/resources/upload/docs/what/policy/ DetroitFoodDesertReport.pdf

Martin, K. S., Havens, E., Boyle, K. E., Matthews, G., Schilling, E. A., Harel, O., \& Ferris, A. M. (2012). If you stock it, will they buy it? Healthy food availability and customer purchasing behaviour within corner stores in Hartford, CT, USA. Public Health Nutrition, 15(10), 1973-1978. https://doi.org/10.1017/S1368980011003387

McLean, B., \& Bates, J. (2003). Financing neighborhood businesses: Collaborative strategies. In S. B. White, R. D. Bingham, \& E. W. Hill (Eds.), Financing economic development in the 21st century (pp. 185-208). Armonk, New York: M. E. Sharpe.

Meredith, R. (1999, May 19). Black man's death raises racial tensions. Retrieved from www.nytimes.com/1999/05/19/us/black-man-sdeath-raises-racial-tensions-in-detroit.html

Mies, M. (1983). Towards a methodology for feminist research. In G. Bowles \& R. D. Klein (Eds.), Theories of women's studies (pp. 117-139). London: Routledge and Kegan Paul. 
Miller, W. R., \& Rose, G. S. (2009). Toward a theory of motivational interviewing. American Psychologist, 64(6), 527-537. https://doi.org/10.1037/a0016830

Min, P. G. (2011). Ethnic solidarity for economic survival: Korean greengrocers in New York City. New York: Russell Sage Foundation.

Moore, L. V., \& Diez Roux, A. V. (2006). Association of neighborhood characteristics with the location and type of food stores. American Journal of Public Health, 96(2), 325-331. https://doi.org/10.2105/AJPH.2004.058040

Morales, A. (2011). Growing food and justice: Dismantling racism through sustainable food systems. In A. H. Alkon \& J. Agyeman (Eds.), Cultivating food justice: Race, class, and sustainability (pp. 149-176). Cambridge, Massachusetts: MIT Press.

Morland, K., \& Filomena, S. (2007). Disparities in the availability of fruits and vegetables between racially segregated urban neighbourhoods. Public Health Nutrition, 10(12), 1481-1489. https://doi.org/10.1017/S1368980007000079

Morland, K., Wing, S., Diez Roux, A., \& Poole, C. (2002). Neighborhood characteristics associated with the location of food stores and food service places. American Journal of Preventive Medicine, 22(1), 23-29. https://doi.org/10.1016/S07493797(01)00403-2

O’Malley, K., Gustat, J., Rice, J., \& Johnson, C. C. (2013). Feasibility of increasing access to healthy foods in neighborhood corner stores. Journal of Community Health, 38(4), 741-749. https://doi.org/10.1007/s10900-013-9673-1

Osypuk, T. L., \& Acevedo-Garcia, D. (2010). Beyond individual neighborhoods: A geography of opportunity perspective for understanding racial/ethnic health disparities. Health \&Place, 16(6), 1113-1123. https://doi.org/10.1016/j.healthplace.2010.07.002

Peterson, I. (1983, March 30). Conflict of cultures resulting in deaths in Detroit. Retrieved from http://www.nytimes.com/1983/03/30/us/conflict -of-cultures-resulting-in-deaths-in-detroit.html

Pothukuchi, K. (2005). Attracting supermarkets to inner-city neighborhoods: Economic development outside the box. Economic Development Quarterly, 19(3), 232-244. https://doi.org/10.1177/0891242404273517

Pothukuchi, K. (2008, April 29). State gambles with families on food stamp distributions. Lansing State
Journal, A5. Available from http://clas.wayne.edu/ Multimedia/clas.wayne.edu/Files/LSJ\%20oped042 908.pdf

Pothukuchi, K. (2011). The Detroit food system report, 200910. Detroit Food Policy Council. Available from http://digitalcommons.wayne.edu/cgi/viewcontent .coi? article $=1005 \&$ context $=$ urbstud_frp

Pothukuchi, K. (2015). Five decades of community food planning in Detroit: City and grassroots, growth and equity. Journal of Planning Education and Research, 35(4), 419-434. https://doi.org/10.1177/0739456X15586630

Pothukuchi, K., Mohamed, R., \& Gebben, D. A. (2008). Explaining disparities in food safety compliance by food stores: Does community matter? Agriculture and Human V alues, 25(3), 319-332. https://doi.org/10.1007/s10460-008-9132-2

Pothukuchi, K. (2012). Building sustainable food systems in a single bottom line context: Lessons from SEED Wayne. Journal of Agriculture, Food Systems and Community Development, 2(3), 103-119. http://dx.doi.org/10.5304/jafscd.2012.023.011

Powell, L. M., Chaloupka, F. J., \& Bao, Y. (2007). The availability of fast-food and full-service restaurants in the United States: Associations with neighborhood characteristics. American Journal of Preventive Medicine, 33(4), S240-S245. https://doi.org/10.1016/j.amepre.2007.07.005

Raja, S., Ma, C., \& Yadav, P. (2008). Beyond food deserts: Measuring and mapping racial disparities in neighborhood food environments. Journal of Planning Education and Research, 27(4), 469-482. https://doi.org/10.1177/0739456X08317461

Reason, P., \& Bradbury, H. (Eds.) (2001). Handbook of action research: Participative inquiry \& practice. London: Sage Publications.

Sanders, J. M., \& Nee, V. (1996). Immigrant selfemployment: The family as social capital and the value of human capital. American Sociological Review, 61(2), 231-249. https://doi.org/10.2307/2096333

Sengstock, M. C. (n.d.). Chaldean Americans. Retrieved February 11, 2014, from http://www.everyculture. $\mathrm{com} / \mathrm{multi} / \mathrm{Bu}-\mathrm{Dr} / \mathrm{Chaldean}-$ Americans.html

Sharkey, J. R., Dean, W. R., \& Nalty, C. (2012). Convenience stores and the marketing of foods and beverages through product assortment. American Journal of Preventive Medicine, 43(3), S109-S115. https://doi.org/10.1016/j.amepre.2012.05.012 
Short, A., Guthman, J., \& Raskin, S. (2007). Food deserts, oases, or mirages? Small markets and community food security in the San Francisco Bay Area. Journal of Planning Education and Research, 26(3), 352-364.

https://doi.org/10.1177/0739456X06297795

Social Compact. (2010). City of Detroit, neighborhood market potential. Retrieved from http://www.degc.org/data/uploads/2009 Detroit DrillDown Report 110209.pdf

Song, H.-J., Gittelsohn, J., Kim, M., Suratkar, S., Sharma, S., \& Anliker, J. (2009). A corner store intervention in a low-income urban community is associated with increased availability and sales of some healthy foods. Public Health Nutrition, 12(11), 2060-2067. https://doi.org/10.1017/S1368980009005242

Sugrue, T. J. (2005). The origins of the urban crisis: Race and inequality in postwar Detroit. Princeton, New Jersey: Princeton University Press.

U.S. Census Bureau. (n.d.-a). Detroit, Michigan Population: Census 2000 and 2010 Interactive Map, Demographics, Statistics, Quick Facts. Retrieved December 18, 2016, from http://censusviewer.com/city/MI/Detroit

U.S. Census Bureau. (n.d.-b). Census of Population and Housing-2000, 2010. Retrieved from https://www.census.gov/prod/www/ decennial.html

U.S. Census Bureau. (n.d.-c). 2007-2011 American Community Survey 5-Year estimates. Retrieved from https://www.census.gov/newsroom/releases/archi ves/news conferences/20121203 acs5yr.html

U.S. Census Bureau. (1967). Wholesale Trade: Area Statistics, Volume 4. Michigan, Table 5-SMSAs (p. 24-12). Washington, D.C.: U.S. Department of Commerce.

U.S. Census Bureau. (1998). Table 18. Population of the 100 Largest Urban Places: 1950. Retrieved from https://www.census.gov/population/www/ documentation/twps0027/tab18.txt

U.S. Census Bureau. (2012). Wholesale trade: Geographic area series, summary statistics for the United States, states, metro areas, counties, and places, 2012. Retrieved from https://factfinder.census.gov/faces/nav/jsf/pages $\angle$ searchresults.xhtml? refresh $=\mathrm{t}$

Vallianatos, M., Azuma, A. M., Gilliland, S., \& Gottlieb, R. (2010). Food access, availability, and affordability in 3 Los Angeles communities, Project CAFE, 2004-2006. Preventing Chronic Disease, 7(2), A27. Available from https://www.ncbi.nlm.nih.gov/ $\mathrm{pmc/articles/PMC2831781/}$

Waterlander, W. E., deBoer, M. R., Schuit, A. J., Seidell, J. C., \& Steenhuis, I. H. M. (2013). Price discounts significantly enhance fruit and vegetable purchases when combined with nutrition education: A randomized controlled supermarket trial. The American Journal of Clinical Nutrition, 97(4), 886-895. https://doi.org/10.3945/ajcn.112.041632

Wekerle, G. R. (1985). From refuge to service center: Neighborhoods that support women. Sociological Focus, 18(2), 79-95. Retrieved from http://connection.ebscohost.com/c/articles/ $11630015 /$ from-refuge-service-centerneighborhoods-that-support-women

Wilson, S., Hutson, M., \& Mujahid, M. (2008). How planning and zoning contribute to inequitable development, neighborhood health, and environmental injustice. Environmental Justice, 1(4), 211-216. https://doi.org/10.1089/env.2008.0506

Yakini, M. (2013, April 17). Racial justice and selfreliance in community food systems [Class lecture]. Wayne State University, Detroit, Michigan.

Zenk, S. N., Schulz, A. J., Hollis-Neely, T., Campbell, R. T., Holmes, N., Watkins, G.,...Odoms-Young, A. (2005). Fruit and vegetable intake in African Americans: Income and store characteristics. American Journal of Preventive Medicine, 29(1), 1-9. https://doi.org/10.1016/j.amepre.2005.03.002

Zenk, S. N., Schulz, A. J., Israel, B. A., James, S. A., Bao, S., \& Wilson, M. L. (2005). Neighborhood racial composition, neighborhood poverty, and the spatial accessibility of supermarkets in metropolitan Detroit. American Journal of Public Health, 95(4), 660667. https://doi.org/10.2105/AJPH.2004.042150 
Appendix. Summary of the Three Action Research Phases

\begin{tabular}{|c|c|c|c|c|}
\hline Action Research Phase & Questions & Data Sources and Methods & Summary Findings & Partners and Participants \\
\hline $\begin{array}{l}\text { Phase I, fall 2008- } \\
\text { winter } 2009 \\
\text { Initial exploration of } \\
\text { problem }\end{array}$ & $\begin{array}{l}\text { 1. What are experiences of CSK } \\
\text { guests of the neighborhood } \\
\text { food environment? } \\
\text { 2. Why do neighborhood stores } \\
\text { not carry or carry only } \\
\text { minimal quantities and } \\
\text { varieties of fresh F\&V? } \\
\text { 3. If fresh F\&V supply and } \\
\text { merchandising were made } \\
\text { convenient, would stores } \\
\text { consistently carry them? }\end{array}$ & $\begin{array}{l}\text { 1. Structured conversations } \\
\text { with CSK guests. } \\
\text { 2. Assessment of all corner } \\
\text { stores within 1-mile (1.6-km) } \\
\text { radius of CSK; interviews } \\
\text { with operators/owners. } \\
\text { 3. Interviews with produce } \\
\text { wholesalers. }\end{array}$ & $\begin{array}{l}\text { 1. CSK guests, residents attest } \\
\text { to steady decline in number } \\
\text { and size of neighborhood } \\
\text { grocery stores. Smaller con- } \\
\text { venience stores and gas } \\
\text { stations with limited inven- } \\
\text { tories come to dominate. } \\
\text { 2. Most stores: “F\&V not part of } \\
\text { business model; not much } \\
\text { success when tried F\&V sales } \\
\text { before." } \\
\text { 3. Three of } 30 \text { stores agree to } \\
\text { participate in project, later } \\
\text { called Detroit FRESH. } \\
\text { 4. Wholesalers interested in } \\
\text { supplying F\&V if enough } \\
\text { stores participate. }\end{array}$ & $\begin{array}{l}\text { 1. Partners: CSK, EWUF staff. } \\
\text { 2. Participants: CSK guests; } \\
\text { other neighborhood residents; } \\
\text { students of Cities and Food } \\
\text { class, winter 2009; store } \\
\text { owners; wholesalers. }\end{array}$ \\
\hline $\begin{array}{l}\text { Phase II, summer 2009- } \\
\text { summer } 2012 \\
\text { Expansion: Recruitment }\end{array}$ & $\begin{array}{l}\text { 1. In an expanded geography, } \\
\text { will more stores in under- } \\
\text { served neighborhoods agree }\end{array}$ & $\begin{array}{l}\text { 1. Assessment of all stores, } \\
\text { expanding incrementally } \\
\text { from Phase I, that are at }\end{array}$ & $\begin{array}{l}\text { 1. Most stores decline to par- } \\
\text { ticipate; our expectation of } \\
\text { an incrementally expanding }\end{array}$ & $\begin{array}{l}\text { 1. Partners: Community organi- } \\
\text { zations in store neighbor- } \\
\text { hoods; CSK, EWUF staff. }\end{array}$ \\
\hline
\end{tabular}

Expansion: Recruitment served neighborhoods agree of stores

(needed for viable supplier logistics, distribution)

PRS Why do they

participate?

2. Are F\&V wholesalers and nonprofit mobile F\&V markets viable distributors?

3. With more stores, can produce distribution become more efficient?

4. Will stores be consistent in their supply of products? What is needed for this to happen?

5. Will residents purchase F\&V from Detroit FRESH stores? expanding incrementally from Phase I, that are at least $1 / 4$ mile $(.4 \mathrm{~km})$ from a full-service supermarket;

interviews with store operators.

2. Store produce purchase receipts; ongoing interviews with participating operators and wholesalers.

3. Notes from door-to-door outreach within $1 / 5$ mile $(.32$ $\mathrm{km}$ ) of store.

4. Notes from regular check-ins with store to verify F\&V supply, troubleshoot.
2. Participants: Store operators; produce wholesalers; WSU students as Detroit FRESH staff and volunteers (including students in the Cities and

Food class, winter 2009 and winter 2010).
2. Twenty-three more stores agree to participate.

3. F\&V wholesalers and mobile markets are viable distributors, within limits.

4. Stores need basic merchandising, display supplies (shelf, baskets, scale, socia marketing materials, etc.), and technical assistance on $F \& V$ handling and storage.

5. Four stores accepting WIC are inconsistent partici-

pants.

6. Increased sales in 6 stores reported immediately 


\begin{tabular}{|c|c|c|c|c|}
\hline Action Research Phase & Questions & Data Sources and Methods & Summary Findings & Partners and Participants \\
\hline & & & $\begin{array}{l}\text { following door-to-door } \\
\text { canvassing. } \\
\text { 7. Some stores in distressed } \\
\text { neighborhoods report lower } \\
\text { overall sales and reduce } \\
\text { participation in or withdraw } \\
\text { from project. }\end{array}$ & \\
\hline $\begin{array}{l}\text { Phase III, summer 2011- } \\
\text { Summer } 2013 \\
\text { Expansion: Under- } \\
\text { standing residents' } \\
\text { relationship to stores }\end{array}$ & $\begin{array}{l}\text { 1. How do neighborhood } \\
\text { residents engage with } \\
\text { Detroit FRESH stores? } \\
\text { 2. Can we help neighborhood } \\
\text { residents increase F\&V } \\
\text { purchases in participating } \\
\text { stores? } \\
\text { 3. Can we increase F\&V } \\
\text { knowledge in neighbor- } \\
\text { hoods with participating } \\
\text { stores? }\end{array}$ & $\begin{array}{l}\text { 1. Door-to-door canvassing and } \\
\text { resident interviews. } \\
\text { 2. Addition of healthy snacking } \\
\text { messaging in stores. } \\
\text { 3. Healthy Food Fairs with par- } \\
\text { ticipating stores; motiva- } \\
\text { tional interviews; survey of } \\
\text { fair participants. } \\
\text { 4. Store owner check-ins and } \\
\text { interviews. } \\
\text { 5. HFFs in partnership with } \\
\text { nonprofit organizations in } \\
\text { store neighborhoods; } \\
\text { motivational interviews; } \\
\text { survey of HFF participants. }\end{array}$ & $\begin{array}{l}\text { 1. Many residents in store } \\
\text { neighborhoods purchase } \\
\text { snacks, soda, and F\&V in } \\
\text { small quantities; most do } \\
\text { not buy large quantities of } \\
\text { F\&V due to high cost and } \\
\text { low supply and variety. } \\
\text { 2. Residents increase F\&V } \\
\text { purchases in participating } \\
\text { Detroit FRESH stores after } \\
\text { canvassing and HFFs, but } \\
\text { sales patterns are not sus- } \\
\text { tained after a few weeks. } \\
\text { 3. Most neighborhoods were in } \\
\text { distress with foreclosures; } \\
\text { overall sales declining in } \\
\text { many participating stores. } \\
\text { 4. Motivational interviews } \\
\text { document increased desire } \\
\text { to consume F\&V; costs } \\
\text { and/or value identified as } \\
\text { challenges. }\end{array}$ & $\begin{array}{l}\text { 1. Partners: Community organi- } \\
\text { zations in store neighbor- } \\
\text { hoods; CSK, EWUF staff. } \\
\text { 2. Participants: Store operators; } \\
\text { produce wholesalers; WSU } \\
\text { students as Detroit FRESH } \\
\text { staff and volunteers. }\end{array}$ \\
\hline
\end{tabular}

Acronyms:

CSK Capuchin Soup Kitchen

EWUF Earthworks Urban Farm

F\&V Fruits and vegetables

$\begin{array}{ll}\text { F\&V } & \text { Fruits and vegetables } \\ \text { HFF } & \text { Healthy Food Fairs }\end{array}$

HFF Healthy Food Fairs

trition Program for Women, Infants and Children

WSU Wayne State University 